University of Michigan Law School

University of Michigan Law School Scholarship Repository

\title{
Christianity and Antitrust
}

\author{
Kenneth G. Elzinga
}

Daniel Crane

University of Michigan Law School, dancrane@umich.edu

Available at: https://repository.law.umich.edu/book_chapters/158

Follow this and additional works at: https://repository.law.umich.edu/book_chapters

Part of the Antitrust and Trade Regulation Commons, and the Religion Law Commons

\section{Publication Information \& Recommended Citation}

Elzinga, Kenneth G. "Christianity and Antitrust." In Christianity and Market Regulation: An Introduction, 74-100. Cambridge: Cambridge University Press, 2021.

This Book Chapter is brought to you for free and open access by the Faculty Scholarship at University of Michigan Law School Scholarship Repository. It has been accepted for inclusion in Book Chapters by an authorized administrator of University of Michigan Law School Scholarship Repository. For more information, please contact mlaw.repository@umich.edu. 


\section{4 \\ Christianity and Antitrust \\ A Nexus}

KENNETH G. ELZINGA AND DANIEL A. CRANE

\subsection{INTRODUCTION}

Ask anyone in the antitrust community the question, "Is there an intersection between contemporary antitrust enforcement and legal training?" and the answer would be, "Yes." Ask any of the same people, "Is there a connection between contemporary antitrust enforcement and the discipline of economics?" and the answer still would be, "Yes." But to the question, "Is there a relationship between Christianity and contemporary antitrust enforcement?" the response is likely an "I don't think so," or, just as likely, a blank stare.

The purpose of this chapter is to consider whether the Christian faith has a nexus with the institution of antitrust. It turns out it doesn't - and it does. For example, Christianity cannot explain why the Herfindahl-Hirschman Index is superior to the four-firm concentration ratio as a measure of industry concentration. Economics can. On the other hand, economics cannot explain why the per se rule against price-fixing is morally appropriate. ${ }^{1}$ The Bible can.

In this chapter, we develop a triad of noteworthy connections between the institution of antitrust and the Christian faith. ${ }^{2}$ First, we explore the historical connection between the institution of antitrust and Christianity. Understanding this link between Christianity and antitrust involves an exercise

The authors thank John Bigelow, Sarah Estelle, P. J. Hill, John Lunn, Edd Noell, Daniel Sokol, and Andrew Yuengert for comments and Charles Smith for excellent research assistance.

1 Economics, as a science, can explain only the consequences for consumers and producers of a market's cartelization.

2 While 3 is a special integer in the Christian faith, we don't contend there is anything inspired by this number of connections. Three is the number of the Trinity, the three persons of the Christian godhead (Matthew 28:19; John 14:26). It also is the number of strands in a cord that the Bible contends is not easily broken or severed (Ecclesiastes 4:22). The Bible also records that Jesus' resurrection took place on the third day (Luke 9:22; Luke 24:5-6; Luke 24:7;

Luke 24:46). 
in intellectual history. Many notable Christian thinkers, from the Catholic Aquinas to the Reformers Luther and Calvin, weighed in on such topics as markets, economic competition, and monopoly. But one person's influence, which we characterize as Christian, played a uniquely formative role in the development of modern antitrust policy - Adam Smith's. If antitrust had an economist patron saint, it would be Adam Smith. Smith's advocacy of the free market's capabilities revealed the importance of maintaining competition in markets. Because economics has made such inroads into antitrust, any link between Adam Smith and the Christian faith reveals a connection between antitrust and Christianity.

Second, we explore a Christian perspective on some of the major themes in antitrust, such as the meaning of rationality and efficiency, the morality of competition, and the importance of innovation. For example, when antitrust models human beings as either buyers or sellers, they are assumed to be rational. In the world of antitrust, the economic agents on the demand side and the supply side of the marketplace compare the price of a good or service (e.g., the value of opportunities foregone) with the benefits (in terms of utility derived from consumption). The decision calculus for buying or selling is based on weighing the costs and benefits inherent in such a choice. Poets, Romantics, Impulse Buyers, Hoarders, Don't-Give-a-Tinker's-Damn Type People, and the Deranged are never actors on the antitrust stage. Only rational actors need apply. In this second portion of our chapter, we explore what it means for antitrust to be based on rationality and we contend that there is a relationship between the rationality of man and the rationality of God, as both man and God are understood and portrayed in Christian theology.

Similarly, we explore how the purported goal of antitrust to promote economic efficiency may, in terms of Christian theology, be connected to good stewardship. The Bible, including several teachings of Jesus, contains many references to the concept of stewardship. Men and women, the only ones in creation who bear God's image, are to be good stewards over God's creation. A steward doesn't manage his or her own assets but rather is entrusted with the property or finances of someone else. While an owner can use their resources any way they want, a steward knows the day will come when his or her employer asks to examine the books. The Christian Scriptures draw this same parallel: humans act as stewards over all "God's good earth" - with a day of reckoning to come. The Bible also teaches the importance of equity, for we learn in the Scriptures that the Lord will judge with equity. ${ }^{3}$ So it is important 
to understand the connection between the institution of antitrust, efficiency, and equity.

The morality of competition as opposed to cooperation is another important theme at the intersection of antitrust and Christianity. Is it ethical for Christian business people to outcompete their commercial rivals? Or does loving one's neighbor as oneself require cooperating rather than increasing one's market share at a rival's expense? Can economic competition be justified on the grounds that, like athletic competition, it brings out the best in everyone?

Another theme intersecting antitrust and Christian doctrine is the role of innovation. While faulty narratives often portray Christianity as antagonistic to innovation, both Christian theology and Church history have been supportive of innovation. From God's mandate to Adam to "be fruitful and multiply and fill the earth and subdue it" in Genesis 1:28 throughout the biblical narrative, Christian doctrine squares with innovative methodologies to improve life and well-being. History chronicles the connection between the spread of Christianity and innovation. The institution of antitrust promotes competitive processes that have often enabled and incentivized innovation. Thus, as antitrust "subdues the earth" through providing a competitive framework with incentives to innovate, it is linked to Christianity's promotion of innovation.

In the third section of this chapter, drawing on the historical precedents and our analysis of antitrust's major themes, we examine a few legal domains of antitrust law. Our focus is on price-fixing. If antitrust were a meal, price-fixing would be the main course, and all the other business practices influenced by antitrust would be the soup, salad, or dessert courses. Every antitrust compliance program starts with warnings about price-fixing. Every antitrust practitioner knows that antitrust takes a dim view of price-fixing. We explore why the Christian faith underscores that view. We also offer some observations on mergers and monopolization.

\subsection{A BRIEF INTELLECTUAL HISTORY OF CHRISTIANITY AND ECONOMIC COMPETITION}

\subsubsection{Medieval and Reformation Thought on Usury and Monopoly}

Although it is customary to think of antitrust law as an artifact of American reaction to late nineteenth-century industrialization, there is a long tradition of intellectual thought and legal regard to the question of monopoly and competition. Influential church leaders have addressed such questions, directly or indirectly, for centuries. 
Competition policy has roots in early Christianity, with edicts by Christian emperors prohibiting such market abuses as monopolies and cartels. ${ }^{4}$ But it was not until the Middle Ages that Christian scholars began to work out general legal, ethical, and economic theories of economic competition. The medieval scholastics conceptualized such questions under the heading of "usury" and "just price theory." Thomas Aquinas asserted that anyone pursuing an excessive profit to the detriment of the public is a dishonest trader. ${ }^{6}$ Under canon law, monopoly profits were considered ill-gotten gains subject to claims for restitution. ${ }^{7}$ Monopoly pricing was considered a deviation from just pricing, a transgression against principles of brotherly love and charity, and injurious to the community. Many writers in the Scholastic tradition, including Nicole Oresme (c. 1320-1382), San Antonio, Archbishop of Florence (1389-1459), and San Bernardino of Siena (1380-1444), wrote strongly against monopolies, either private or state-granted, and price-fixing cartels. ${ }^{8}$ Although allowing that goods generally did not have an objective value and that interplay between supply and demand was necessary to determine the just price, medieval rules across Europe imposed extensive price controls in an effort to balance the interests of producers and consumers. ${ }^{9}$

By the time of the Reformation, an antimonopoly tradition had firmly taken root in the Christian mind. ${ }^{10}$ Martin Luther, influenced by the Scholastic tradition in economic matters, lumped cartels and monopolies under the wider rubric of "usury" and the "lust for profits," by which he meant charging more than a fair price. Luther saw a rising moral problem in sixteenth-century Protestant Germany and identified cornering markets, or what the British common law called forestalling, regrating, or engrossing, as a particular problem:

Again, there are some who buy up the entire supply of certain goods or wares in a country or a city, so that they may have those goods solely in their own power and can then fix and raise the price and sell them as dear as they like or

4 W. W. Thornton, A Treatise on Combinations in Restraint of Trade, $\$ 20$ (2d ed. 1928).

5 See generally Marcia L. Colish, Medieval Foundations of the Western Intellectual Tradition 400-1400 (New Haven, CT: Yale University Press, 1997), pp. 330-334.

6 Raymond De Roover, "Monopoly Theory Prior to Adam Smith: A Revision," Quarterly Journal of Economics, vol. 65, no. 4 (1951), pp. 492-524.

7 Ibid.

8 Ibid., pp. 498-499.

9 Colish, Medieval Foundations.

${ }^{10}$ For a non-Reformation analysis of the relationship between antitrust and Christianity, see Tihamer Toth, "Is There a Vatican School for Competition Policy?" Loyola University Chicago Law Journal, vol. 46, no. 3 (2015), pp. 583-616. 
can. Now I have said above that the rule that a man may sell his goods as dear as he will or can is false and unchristian. It is far more abominable that one should buy up the whole commodity for that purpose. Even the imperial and temporal laws forbid this and call it "monopoly," i.e., purchase for selfinterest, which is not to be tolerated in city or country, and princes and lords would stop it and punish it if they did their duty. Merchants who do this act just as though God's creatures and God's goods were made for them alone and given to them alone, and as though they could take them from other people and set on them whatever price they chose. ${ }^{11}$

Luther contrasted monopolistic market-cornering with the Genesis 47 account of Joseph buying up grain for storage during the seven fat years in anticipation of the coming seven lean years. This was not monopolistic, according to Luther, but rather a "common and honest purchase" because Joseph didn't prevent anyone else from buying and Joseph was motivated, through God's wisdom, by the public good rather than personal gain. Because antitrust economics does not distinguish whether monopoly profits are used for personal gain or personal philanthropy (the resource misallocation being the same), Luther's exegesis would not persuade most antitrust practitioners. Joseph's buying the grain in the seven fat years appears to the economist to be a voluntary market transaction. Likewise, when he sold the grain during the seven lean years, Joseph seems to the economist to have acted very much as a monopolist, forcing the Egyptians to give up everything they owned to Pharaoh. ${ }^{12}$

Luther also railed against predatory pricing:

When some see that they cannot establish their monopolies in any other way because other people have the same goods, they proceed to sell their goods so cheap that the others can make no profit, and thus they compel them either not to sell at all, or else to sell as cheap as they themselves are selling and so be ruined. Thus they get their monopoly after all. These people are not worthy to be called men or to live among other men, nay they are not worth exhorting or instructing; for their envy and greed is so open and shameless that even at the cost of their own losses they cause loss to others, so that they may have the whole place to themselves. The authorities would do right if they took from such people everything they had and drove them out of the country. It would scarcely have been necessary to tell of such doings, but I wanted to include them so that it might be seen what great knavery there is

${ }^{11}$ Martin Luther, "On Trading and Usury," in Works of Martin Luther (Philadelphia, PA: A. J. Holman Company, 1915), pp. 26-27.

${ }^{12}$ In addition to monopolies, Luther singled out price-fixing cartels as pernicious, and even described an issue of considerable interest to modern economics: mechanisms by which cartelists enforce their agreement internally and penalize "cheating." Ibid., p. 30. 
in trade, and that it might be plain to everybody how things are going in the world, in order that everyone may know how to protect himself against such a dangerous class. ${ }^{13}$

Luther did not offer an opinion about how often business firms might operate at the "cost of their own losses" and under what conditions pricing below cost could become profitable. Contemporary antitrust scholarship has since examined this question in detail. While predatory pricing is actionable under the Sherman Act, antitrust now offers a cautionary perspective as to the likelihood of predatory pricing as a plausible monopolizing strategy. ${ }^{14}$ The most recent pronouncements of the Supreme Court have followed in the grain of the academic scholarship on predatory pricing. ${ }^{15}$

Max Weber famously anointed John Calvin the father of modern capitalism due to the Protestant work ethic, but Calvin also was important to postReformation economics by breaking with Luther and the medieval tradition on usury. Calvin argued that Scripture did not condemn all lending for interest, but only unscrupulous lending to the poor, loans that benefited only the lender, and lending at excessive rates. ${ }^{16}$ While Calvin did not deal as explicitly as Luther with monopolies and cartels, to the extent that the medieval Christian conception of monopoly was bound up in the conception

13 Ibid., pp. 28-29.

14 The taproot of this antitrust scholarship on this subject is John McGee, "Predatory Pricing: The Standard Oil (N.J.) Case,” Journal of Law \& Economics, vol. 1 (October 1958), pp. 137-169 and "Predatory Pricing Revisited," Journal of Law \& Economics, vol. 23 (October 1980), pp. 289-230. For a summary of the issues, see Patrick Bolton, Joseph F. Brodley, and Michael Riordan, "Predatory Pricing: Strategic Theory and Legal Policy," Georgetown Law Journal, vol. 88, no. 1 (August 2000), pp. 2239-2330; and Kenneth G. Elzinga and David E. Mills, "Predatory Pricing and Strategic Theory," Georgetown Law Journal, vol. 89 (August 2001), pp. 2475-2494.

15 Matsushita Electric Industrial Co. v. Zenith Radio, 475 U.S. 574 (1986). Here Justice Powell concluded, "There is a consensus among commentators that predatory pricing schemes are rarely tried, and even more rarely successful." Matsushita at p. 589. The Court's skepticism about the efficacy of predatory pricing continued in Liggett Group, Inc. v. Brown \& Williamson Tobacco Corp., 509 U.S. 209 (1993). This case is often referred to as Brooke Group because the Brooke Group acquired Liggett in the course of the litigation. In more recent cases, like Pacific Bell Telephone Co. v. Linkline Communications, Inc., 555 U.S. 438 (2009) and Weyerhaeuser Co. v. Ross-Simmons Hardwood Lumber Co., 549 U.S. 312 (2007), the Supreme Court has continued to hold to a skeptical view of predatory pricing cases. However, some lower courts have begun to cite a "post-Chicago" literature that views predatory pricing as a greater threat, even though these cases have still tended to reject predatory pricing liability on the facts before them. See United States v. AMR Corp., 335 F.3d 1109 (10th Cir. 2003) (observing that, in light of Post-Chicago scholarship, the court would not approach predatory pricing claims "with the incredulity that once prevailed").

16 Kathryn D. Blanchard, The Protestant Ethic or the Spirit of Capitalism (Eugene, OR: Cascade Books, 2010), pp. 36-40; John Calvin, Letter of Advice on Usury (1545). 
of usury, Calvin freed Christian thought to deal with economic matters - and the role of capital and investment in particular - in a more open light. In so doing, he set the stage for the most important Christian writer of all time on economics - Adam Smith.

\subsubsection{Adam Smith and His Immediate Influences}

Conventional wisdom identifies Adam Smith as the father of modern economics. ${ }^{17}$ Because antitrust is now joined at the hip with economics, it is worth revisiting the theological roots of Smith's economic contribution. While the intellectual and amicable connection between Smith and David Hume (no friend of the Christian faith) is well known, ${ }^{18}$ and while most scholars consider Smith to have been a deist, Smith's intellectual debt to Presbyterian clergy is less commonly acknowledged. ${ }^{19}$ Hence it is fitting to be reminded of what Smith wrote about this group:

There is scarce perhaps to be found anywhere in Europe a more learned, decent, independent, and respectable set of men, than the greater part of the Presbyterian clergy of Holland, Geneva, Switzerland, and Scotland. ${ }^{20}$

These men were scholar-pastors who were deeply affected by the Protestant Reformation. ${ }^{21}$ While Smith is commonly thought to have made an economic case for free markets and voluntary exchange, the Reformers who influenced Smith were making a theological case for free markets and voluntary exchange.

${ }^{17}$ Economists often remark, "It's all in Smith," meaning that the substantive issues and principles of economics have their taproot in The Wealth of Nations. A variation of this among economists is that "It's all in Marshall," referring to Alfred Marshall's magnum opus, Principles of Economics. Marshall's Principles was first published in 189o, the year antitrust was established as a national policy in the United States with the passage of the Sherman Act.

18 David Hume, The Life of David Hume, Esq: Written by Himself. To Which Is Added, a Letter from Adam Smith, LL.D. to William Strahan, Esq. (Ann Arbor: University of Michigan Library, 2007), originally published in Dublin, 1777. The latest scholarship regarding Smith and Hume's friendship is Dennis C. Rasmussen, The Infidel and the Professor (Princeton, NJ: Princeton University Press, 2017).

19 We are indebted to Samuel Gregg's scholarship in this regard. See Samuel Gregg, "Commercial Order and the Scottish Enlightenment: The Christian Context," in Christian Theology and Market Economics, eds. Ian R. Harper and Samuel Gregg (Cheltenham: Edward Elgar, 2008), pp. 43-59.

20 Adam Smith, An Inquiry into the Nature and Causes of the Wealth of Nations, vol. 2, ed. Edwin Cannan (London: Methuen, 1904), p. 295.

${ }^{21}$ Countries such as France, Spain, and Italy, where the Reformation did not advance, are absent from Smith's list. Notably, Germany, the home of Martin Luther, also is absent. 
Smith was a student of Francis Hutcheson, who was both a minister in the Church of Scotland and a professor at Glasgow. Hutcheson was influenced by Gershom Carmichael, a Presbyterian minister and a professor at St. Andrews and Glasgow. Carmichael was himself influenced by the natural law teachings of Hugo Grotius and Samuel von Pufendorf. If one were writing in the vernacular of the King James Version, Grotius and Pufendorf begat Carmichael, Carmichael begat Hutcheson, Hutcheson begat Smith, and Smith described the workings of what he called the "simple and obvious system of natural liberty." 22 In what follows, we describe the "begats." (Note: See Chapter 10 for an analysis of Smith, Pufendorf, and Hutcheson's views on price controls.)

Smith's work organized an economic way of thinking in an important - and now iconic - fashion. But some of his important principles had already been developed by "the Presbyterian clergy." For example, one of the most famous principles of economics, featured prominently in Smith, is that specialization and division of labor generate economic growth. Smith encountered this principle as a student of Hutcheson. ${ }^{23}$ Hutcheson, the clergyman-professor, described "demand and supply" with as much clarity as Smith, his student:

We shall find that the prices of goods depend on these two jointly, the demand on account of some use or other which many desire, and the difficulty of acquiring, or cultivating for human use. ${ }^{24}$

What is important for our analysis is not that Hutcheson, a professor of moral philosophy, was teaching economic principles before Smith was writing them down. Rather, for Hutcheson, economics as a discipline formed and generated these principles from a moral foundation. Market processes worked best not when people were driven by greed, but when they were motivated by biblical virtues of saving and diligent labor. Smith heard these (literally) "Proverbial" virtues taught by his teacher Hutcheson. ${ }^{25}$ Smith's principle of self-interest was expressed famously with his words,

22 Smith, An Inquiry into the Nature, p. 184.

23 "Nay tis' well known that the produce of the labours of any given number, twenty, for instance, in providing the necessaries or conveniences of life, shall be much great by assigning to one, a certain sort of work of one kind, in which he will soon acquire skill and dexterity, and to another assigning work of a different kind, than if each one of the twenty were obliged to employ himself, by turns, in all the different sorts of labour requisite for his subsistence, without sufficient dexterity in any." Frances Hutcheson, A System of Moral Philosophy, In Three Books (Glasgow, 1755).

24 Ibid., p. 54.

25 Proverbs 6:6-8; Proverbs 21:5; Proverbs 21:20. 
It is not from the benevolence of the butcher, the brewer, or the baker that we expect our dinner, but from regard to their own interest. We address ourselves, not to their humanity but to their self-love, and never talk to them of our own necessities but of their advantages. ${ }^{26}$

Smith never uses the word greed as the motivator of buying and selling.

Smith's principle of self-interest finds its roots in his contention that, "In civilized society, [man] stands at all times in need of the cooperation and assistance of great multitudes, while his whole life is scarce sufficient to gain the friendship of a few persons." ${ }^{27}$ It is this need for interaction between the buyer and seller of goods in which Love, the chief of Christian virtues, involves itself in the market economy.

Smith recognized the need for and presence of the virtue of Love in a market economy. Writing in The Theory of Moral Sentiments, he declared, "Humanity does not desire to be great, but to be beloved. It is not in being rich that truth and justice would rejoice, but in being trusted and believed, recompenses which those virtues must almost always acquire." ${ }^{28}$ On this very idea of "being trusted and believed" most market interactions depend. ${ }^{29}$

Drawing from Hutcheson's ideas regarding the virtues of man, Smith recognized that the duties of man and God in extending benevolence differ practically. Smith observed that the notion that humans could manufacture "the general happiness of mankind" would require that people do something beyond their capabilities, but precisely in the abilities and desire of God. ${ }^{30}$

The administration of the great system of the universe ... the care of the universal happiness of all rational and sensible beings, is the business of God, and not of man. To man is allotted a much humbler department, but one much more suitable to the weakness of his powers, and to the narrowness of his comprehension - the care of his own happiness, of that of his family, his friends, his country. ${ }^{31}$

${ }_{26}$ Smith, Inquiry into the Nature, p. 16.

27 Ibid.

28 Adam Smith, The Theory of Moral Sentiments, ed. Dover Philosophical Classics (New York: Dover, 2006), p. 161.

29 There is, in fact, a branch of economic theory that explicitly pertains to "being trusted and believed." The literature regarding incentive compatibility in the context of asymmetric information explains how individuals reveal their truthful incentives in a market transaction only under certain rules that provide motivation to do so. Incentive compatible allocations that might yield Pareto efficient allocations are those for which the holders of private information will be willing to reveal it. See John O. Ledyard, "Incentive Compatibility," in Allocation, Information, and Markets (London: Palgrave Macmillan, 1989), pp. 141-151.

$3^{\circ}$ Ronald Coase, "Adam Smith's View of Man," Journal of Law and Economics, vol. 19 (1976), p. 17.

${ }^{31}$ Smith, Theory of Moral Sentiments, p. 238. 
Smith may even have drawn the title of his magnum opus from the title of his mentor's book. The full title of Smith's most famous work is: An Inquiry into the Nature and Causes of the Wealth of Nations (1776). The full title of Hutcheson's magnum opus is: An Inquiry into the Origin of Our Ideas of Beauty and Virtue (1725).

As mentioned earlier, Hutcheson was the most notable student of Carmichael in moral philosophy at the University of Glasgow. He then succeeded Carmichael on the faculty at Glasgow. Carmichael's convictions were derived from the works of Grotius and Pufendorf, who built upon the natural law tradition of Thomas Aquinas, and are responsible for Christianity's natural law tradition as applied to law and commerce. These predecessors of Adam Smith constructed two pillars that are predicates for antitrust to make sense. First, the law is to protect private property from theft and expropriation because there is a divine mandate for individuals to be able to exclude others from the use of their private property. Second, the law is to protect the market exchange of private property rights because there is a divine basis for individuals to engage in voluntary exchange of property. ${ }^{32}$

But, even with these two pillars in place, both Grotius and Pufendorf had concerns about the prospect of monopoly in a market-based economy. The views of Grotius on monopoly are expressed with examples of monopolizing (or "engrossing") agricultural products and the naval practices of the Spaniards:

32 Pufendorf anticipated the State granting property rights to deter free riding on risky investments. He wrote:

Besides, the Magistrate may give one Man, or one Company of Men the sole Power of Importing certain Commodities from certain Places, exclusive of all others. And there may be several good Reasons for the granting such a Privilege. For it requires vast Charges to settle a Trade with a very remote Nation, and perhaps after great Expenses it may not succeed at all; and therefore the Authors of such a Commerce ought in reason to have Security, that others may not intercept gratis what they have established at their great Risk and Charge; and besides such privileged Companies are better able to assist the Public with their Riches; upon any Emergencies, than private Persons: By this means too a greater Trade may be carried on, and with better Credit: Nor is this Method liable to so many Tricks and Shifts, since the Gain comes into the common Bank to be divided proportionally amongst them all. But as for these Privileges, a prudent Government will not grant 'em, but where the Commodities are imported from remote Places, and with great Hazard; and which do not so much concern the Necessities as the Superfluities of Life. Not even then must the Merchants be allowed to enhance the Price of those Things at their Pleasure; for it is against Reason to give a few an opportunity of scraping up exorbitant Riches out of the Fortunes of the rest, when the Public gets nothing by it. (Samuel von Pufendorf, Of the Law of Nature and Nations: Eight Books, 1729. Book V. Chapter V. Section VII). 
What, therefore, may seem so unjust as that the Spaniards should have the whole world tributary, so that they neither buy nor sell but at their pleasure? We hate and also punish engrossers of corn or other commodities in all cities. Nor doth any trade of life seem so wicked and hateful as this engrossing of corn. And that worthily too. For they do injury to nature which is plentiful and liberal to all in common. Nor is it to be thought that negotiation was found for a few men's uses, but to the end that what was wanting unto one should be recompensed through the plenty of another yet with a just advantage or profit propounded unto all who should undertake the danger and labor of transporting. 33

Pufendorf expanded upon Grotius' work, ${ }^{34}$ describing monopoly as contrary to natural law. He did not mince words:

But a Monopoly, properly so called, as having the Force of Privilege, cannot be set on foot by private Men: For how can a private Man justify his hindering others from meddling with such a sort of Commodity, when he has no Command over, nor can lawfully use Force against them? And

33 Hugo Grotius, The Free Sea, trans. Hakluyt. 1609. Reprint (Indianapolis, IN: Liberty Fund, 2004), p. 56.

34 Despite being extremely similar in ideology, Pufendorf did not always see eye to eye with Grotius about monopoly. Grotius explains his justification of some natural monopoly structures, incorporating a biblical reference, in this excerpt:

All Monopolies are not repugnant to the Law of Nature, for they may sometimes be permitted by the Sovereign upon a just Cause, and at a certain Rate; as may appear from the Example of Joseph, when he was Governor of Aegypt: So also under the Romans, the Alexandrians had the Monopoly, as Strabo tells us, of all Commodities brought from the Indies and Aethiopia. The like may be done by private Persons, provided they are contented with a reasonable Profit. But they, who, as the Oylmen in the Velabrum, do purposely combine to advance the Value of their Wares above the highest Degree of the current Price, and those also who use Force or Fraud to prevent the Importation of any greater Quantity, or else agree to buy up all, in Order to sell them again, at a Rate very exorbitant, considering the Season, commit an Injustice, and are obliged to make Amends and a Reparation for it. If indeed they do by any other Means hinder the bringing in of Goods, or ingross them to themselves, to vend them dearer, tho' at a Price not unreasonable for the Season, they act against the Rules of Charity as St. Ambrose proves by several Arguments, in his third Book of Offices, but properly speaking, they violate no Man's Right. (Hugo Grotius, The Rights of War and Peace, 1625. Reprint [Indianapolis, IN: Liberty Fund, 2005], vol. 2, chapter 12, section 16)

But Pufendorf disagrees with Grotius on the basis of Joseph's lack of use of market power:

Grotius bring the Example of Joseph, when he was Viceroy of Egypt, in Justification of Monopolies; tho' that Example is not much to the Purpose: For neither did the King hinder others from buying up the Corn in the Years of Plenty, nor any from selling, who had too much: Neither had the Alexandrians in Strabo the Monopoly of Indian and Ethiopian Commodities from any Privilege, but from the Situations of the Place. (von Pufendorf, Of the Law of Nature and Nations) 
therefore the Monopolies of private Men are spurious and illegal, and do not depend upon Rights and Privileges, but are generally carried on by clandestine Frauds and Combinations: As if some few by a Trick should debar others from Trading to those Places from whence they have their Commodities, or should hinder those that have them from bringing them to Market: Or, if they should enter into a Combination to buy up all such sort of Commodities, and then stifle them, that so the Scarcity may enhance the Price. Against whom may be applied that of Apollonius Tyanaus in Philostr. in the Beginning. "The Earth is the Mother of all, for she is just; but you being unjust have made her only a Mother to your selves.' The Knavery of such ought as much to be corrected, as those who enter into Compact to raise extravagantly the Prices of other things, by agreeing privately to sell nothing under such a Rate: Which piece of Roguery Labourers and Workmen are sometimes guilty of. ${ }^{35}$

In the quotation that follows, Pufendorf even anticipated Holmes' dissent in the Northern Pacific case. ${ }^{36}$

In this place something maybe expected to be said concerning Monopolies, Whether any, or all of them be against the Law of Nature, or no? For 'tis an odious Name, and the Laws of many States brand it grievously. But here we must exempt several Things from the insidious Title of Monopolies, which indeed are not such. For sure 'tis prohibited by no Law, nor can it come under the Name of a Monopoly, if only one Man, in any Town, has got the way of making some sort of Manufacture, or if one Man only has got such a sort of Grain in his Ground, or if some certain Commodity be the Produce only of one particular Country. Since there is no such 'Produce of Alume in any other Country, which yet is of great Use, it is not to be wondered at, that the Lipareans have the Monopoly of it, and setting what Prices they please upon it, make vast Returns.' For Monopolies, as such, imply that others too would sell the same, did not one Man ingross the whole Trade to himself. ${ }^{37}$

35 Ibid.

36 "The law, I repeat, says nothing about competition, and only prevents its suppression by contracts or combinations in restraint of trade, and such contracts or combinations derive their character as restraining trade from other features that the suppression of competition alone. To see whether I am wrong, the illustrations put in the argument are of use. If I am, then a partnership between two stage coach drivers who have been competitors in driving across a state line, or two merchants once engaged in rival commerce among the States whether made after or before the act, if now continued, is a crime. For, again I repeat, if the restraint on the freedom of the members of a combination caused by their entering into a partnership is a restraint of trade, every such combination, as well the small as the great, is within the act." Northern Securities Co. v. United States, 193 U.S. 197, 410 (1904).

37 Pufendorfs paradigm of natural law anticipates the common law on restraint of trade with these words: "But if a Man, without contracting with the Others, should of his own Head aim 
Gregg summarizes the Grotius-Pufendorf intersection this way:

Grotius's Mare Liberum (1609) ... made a powerful case for the liberty of all people of all nations to use the sea to trade freely (1609, 2004, Pp. 49-51) and is commonly regarded as one of the first early-modern arguments against monopolies.

Widely regarded as one of Grotius's most prominent intellectual disciples, a considerable portion of Pufendorf's theological and jurisprudential writings were concerned with applying Grotius's schema to a range of thencontemporary issues ... [for example] when it came to the question of economic value and price, Pufendorf argued that the determining factors were a good's relative scarcity and its subjective utility.

$$
\text { (Pufendorf, 1673, 2004, pp. 140-145) })^{38}
$$

With Grotius and Pufendorf as the foundation, let's return to how Carmichael built upon it. He wrote this about competition:

[The] further expenditure of labour and industry which the interest of human society requires in the way of competition in cultivating the things of the earth, is likely to achieve a greater stock of a certain kind of thing than our own personal use requires. In return for these we can acquire, by the use of agreements, other things that are useful to us. This further fruit of our labour should not be taken from us, provided we got it without fraudulent and unfair oppression of others, who should always be left the opportunity to get what their own use requires under fair conditions. ${ }^{39}$

Gregg summarizes the importance of Carmichael on competition this way:

Carmichael highlights the importance of competition in stimulating the human creativity that delivers a surplus of privately-owned goods that people can then trade via voluntary transactions, while simultaneously insisting that others should have the opportunity to enter the circle of exchange. The implication is that it is unjust and not in the interests of the common good to unreasonably restrict market exchange. This amounts to a Christian naturallaw argument for the moral necessity of free trade - an argument that would have resonated throughout much of the Scotland of Carmichael's time..$^{\circ}$

at a Monopoly, by hindering some by Force, and others by clandestine Contrivances, from coming to the same Place, and by that means lay a Necessity upon all others to buy of him, it is plain that he offends against the Law of Humanity, and impudently breaks in upon the Liberty of the rest." von Pufendorf, Of the Law of Nature and Nations.

$3^{8}$ Gregg, "Commercial Order and the Scottish Enlightenment," p. $4^{8}$.

39 Gershom Carmichael, Natural Rights on the Threshold of the Scottish Enlightenment, eds. James Monroe and Michael Silverthorne (Indianapolis, IN: Liberty Fund, 2002), p. 95.

$4^{\circ}$ Gregg, "Commercial Order and the Scottish Enlightenment," p. 50. 
These words resonate "throughout much of the antitrust community of today" because Carmichael understood that competition was better than planning, that private property was a prerequisite of competition, that competition produced a "surplus" (or economic growth), that competition should not be to the benefit of some but not others, that competition should not be unreasonably restricted, and that there was a biblical basis for competition being given free reign. As Gregg summarized the linkage from Grotius and Pufendorf to Carmichael to Smith,

Perhaps Gershom Carmichael's greatest contribution to the Scottish Enlightenment was to re-introduce the natural-law tradition, long dormant in Scotland since the Reformation, back into Scottish learning. While figures such as Hume reflected upon commercial society's emergence in ways that marked a break with Christian belief about human nature, most Scottish Enlightenment scholars - including, to a certain extent, Adam Smith, engaged in the same enterprise primarily within the context of the powerful theological and philosophical legacy bequeathed by the 17th century Protestant natural law tradition associated with figures such as Hugh Grotius (1583-1645) and Samuel von Pufendorf $(1632-94) .^{41}$

The encomium Smith gives to "Presbyterian clergy" is, at its taproot, recognition of a theory of law and commerce that was put forth by scholar-pastors who applied reason to Scripture. The result was a "natural law" that - like antitrust law - is friendly to market exchange, not hostile to it. ${ }^{42}$

Later scholars had no qualms about connecting Adam Smith's invisible hand to a providential order. Richard Whately wrote, "Man is, in the same act, doing one thing, by choice, for his own benefit, and another, undesignedly, under the care of Providence, for the service of the community." 43 In writing these words, Whately was influenced by Smith. ${ }^{44}$ Thomas Chalmers rewrote the principle of the invisible hand this way:

The greatest economic good is rendered to the community by each man being left to consult and to labour for his own particular good - or, in other words, a more prosperous result is obtained by the spontaneous play and busy

41 Ibid., p. 47 .

$4^{2}$ Gregg contends that in Hutcheson's System of Moral Philosophy, the author further developed "economic ideas found in Grotius and Pufendorf, mediated through Carmichael, many of which anticipate theories subsequently developed in Smith's The Wealth of Nations" $(1776,1904)$.

43 Richard Whately, Introductory Lectures on Political Economy (London: B. Fellowes, 1832), p. 103.

44 Elizabeth Jane Whately, Life and Correspondence of Richard Whately, DD. (London: Longmans, Green, 1866). 
competition of many thousand wills, each bent on the prosecution of its own selfishness, than by the anxious superintendence of a government, vainly attempting to medicate the fancied imperfections of nature. ${ }^{45}$

In the ability of markets to translate the self-interest of economic agents into the good of others, Chalmers claimed this "bespeaks a higher Agent, by whose transcendental wisdom it is, that all is made to conspire so harmoniously, and to terminate beneficially." ${ }^{6}$ If Providence has ordained that consumers appeal to the self-interest of sellers, who then compete in the marketplace for consumer patronage, any agent that eliminates competition, or suppresses it through regulation, squelches this "transcendental wisdom." This means that any institution that preserves and promotes market competition is an agent of Providence. Central planners search for proper levers of government regulation to allocate society's scarce resources. The default position of antitrust is to search for a market-based solution to allocate society's scarce resources. Grotius, Pufendorf, and their progeny presumably applaud antitrust from the heavenly sidelines.

Modern theorists often justify antitrust law in purely consequentialist terms. For example, Herbert Hovenkamp, a leading antitrust scholar and custodian of the highly influential Areeda-Turner treatise, asserts that antitrust law has "no moral content." 47 But the story of antitrust is not one of legal doctrine shorn of natural law. ${ }^{4}$ The natural law that informed Adam Smith - the natural law two pillars are private property and voluntary exchange - remains fundamental to the institution of antitrust. Indeed, the institution of antitrust has no basis apart from a certain - if we may use the word - "reverence" for private property and voluntary exchange.

Joseph Schumpeter, in his classic History of Economic Analysis, claimed that economics, as a discipline, "gained definite if not separate existence" by

45 Thomas Chalmers, On the Power, Wisdom, and Goodness of God (London: Bell and Daldy, 1869), p. 238.

$4^{6}$ Ibid., p. 239 .

47 Herbert Hovenkamp, “Antitrust Violations in Securities Markets," Journal of Corporation Law, vol. 28 (2003), pp. 607, 609; see also Herbert Hovenkamp, The Antitrust Enterprise: Principle and Execution (2005), pp. 10, 54 (stating that antitrust is only concerned with the economic, not the moral, implications of conduct).

$4^{8}$ Alvey offers two reasons why economics is, today, largely shorn of "moral concerns." "First, the natural sciences came to be seen as successful, and the attempt was made to emulate that success in economics by applying natural science methods, including mathematics, to economic phenomena. Second, the self-styled economic science came to adopt positivism, which ruled out moral issues from science itself." James E. Alvey, "A Short History of Economics as a Moral Science," Journal of Markets and Morality, vol. 2, no. 1 (Spring 1999), Pp. 53-73. 
way of Christianity's influence on law. ${ }^{49}$ Jacob Viner, another historian of economic thought who paralleled Schumpeter in stature, wrote: "I am obliged to insist that Adam Smith's system of thought, including his economics, is not intelligible if one disregards the role he assigns in it to the teleological elements." 50

\subsection{ANTITRUST THEMES: RATIONALITY, EQUITY, EFFICIENCY, COMPETITION, INNOVATION}

\subsubsection{Antitrust and Rationality}

The first thematic connection between antitrust and the Christian faith is theological: From whence cometh the basis for the institution of antitrust? The Christian faith offers a foundation for the same rationality upon which antitrust enforcement is founded. ${ }^{51}$ In his book, The Victory of Reason, Rodney Stark explains:

The Christian image of God is that of a rational being who believes in human progress, more fully revealing himself as humans gain the capacity to better understand. Moreover, because God is a rational being and the universe is his personal creation, it necessarily has a rational, lawful, stable structure, awaiting increased human comprehension. ${ }^{52}$

After creating "male and female" in his own image, "God blessed them and said to them, "Be fruitful and increase in number; fill the earth and subdue it ..." 53 In what has come to be called the creation mandate, God directs men and women to be His stewards over the earth. This means that human beings unlike all other living creatures - have been given a form of dominion over

49 "It is within [the scholastics'] systems of moral theology and law that economics gained a definite if not separate existence, and it is they who come nearer than does any other group to having been the 'founders' of scientific economics." Joseph Schumpeter, History of Economic Analysis (New York: Oxford University Press, 1954), p. 97.

$5^{\circ}$ Jacob Viner, The Role of Providence in the Social Order (Philadelphia, PA: American Philosophical Society, 1972), pp. 81-82.

${ }^{51}$ This is a very different topic than the familiar terrain, already explored, of the basis of antitrust in English common law or the legislative history of antitrust law. See William Letwin, "The English Common Law Concerning Monopolies," University of Chicago Law Review, vol. 21, no. 3 (1954), p. 355; and Donald Dewey, Monopoly in Economics and Law (Chicago, IL: Rand McNally and Company, 1959), especially chapters IX and X; and Hans Thorelli, The Federal Antitrust Policy (Baltimore, MD: Johns Hopkins Press, 1955).

52 Rodney Stark, The Victory of Reason: How Christianity Led to Freedom, Capitalism, and Western Success (New York: Random House, 2007), pp. 11-12.

53 Genesis 1:27-28. 
God's creation, not out of merit, but rather because God was pleased to create them in His image. Man is able to exercise good stewardship over the earth because God, as Stark describes it, created the earth as a "rational, lawful, stable structure, awaiting increased human comprehension." As the field of antitrust has grown in its "human comprehension," antitrust is better positioned to "subdue the earth" to the extent it applies a "rational, lawful, stable structure" to the task of stewardship that the Bible claims God ceded to mankind. ${ }^{54}$ The rationality postulate undergirds most of economic analysis.

A presupposition of antitrust is that the rational economic actor model applies to both buyer and seller. Where antitrust economics stands in tension with the Christian faith is where Christianity also sees men and women as sinners, in need of redemption offered in the Gospel through Jesus Christ. Whereas antitrust seeks to optimize the choice set that consumers face, Christianity questions some of the choices that buyers and sellers make. Consumer preferences, to be met by competing sellers at congenial prices, are not a necessary or sufficient condition for human flourishing.

Describing economic agents through the lens of Christian theology, Brennan and Waterman explain:

Their desires do not reflect their true interest. Their actual behavior has no presumptive normative authority. Man is sinful. Agents know what they ought to do, but they do something else ... As St Paul puts it: "That which I would not, that I do. And that which I would, I do not." 55

Thus, while antitrust seeks the optimization of consumer choices, ${ }^{56}$ Christianity questions the morality of those choices. Paul's writings in Romans 7:15, referenced above, describe the insufficiency of consumer choice alone for human flourishing. However, as we've argued in this section, the fundamental rationality necessitated by antitrust's rational actor model

54 Pufendorf described the creation mandate this way: "For, not being born for himself alone, but being therefore furnished with so many excellent Endowments, that he may set forth his Creator's Praise, and be rendered a fit Member of Human Society; it follows hence, that it is his Duty, to cultivate and improve those Gifts of his Creator which he finds in himself, that they may answer the End of their Donor; and to contribute all that lies in his Power to the Benefit of Human Society." Samuel von Pufendorf, The Whole Duty of Man According to the Law of Nature, 1673. Reprint (Indianapolis, IN: Liberty Fund, 2003).

55 Geoffrey Brennan and Anthony M. C. Waterman, "Christian Theology and Economics: Convergence and Clashes," in Christian Theology and Market Economics, eds. Ian R. Harper and Samuel Gregg (Northampton, MA: Edward Elgar, 2008), p. 91.

${ }^{6}$ Economics as a science lacks the language to create "moral norms," but rather the moral concerns of individuals within the context of Pareto efficiency, which analyzes individuals" preferences as data apart from value judgments. While economic theory provides no basis for value judgments, Christianity stands ready to fill the gap. 
coincides with the biblical mandate to "subdue the earth" along with the biblical description of God as a rational, ordered being.

\subsubsection{Equity and Efficiency ${ }^{57}$}

The pursuit of equity and efficiency provide us with an additional intersection between Christianity and the institution of antitrust. Throughout the biblical narrative, the revealed nature of God is one of equity and justice..$^{8}$ In the Sermon on the Mount, Jesus even blesses the materially poor. ${ }^{59}$ Additionally, the Bible upholds the wise allocation of resources in an efficient manner. ${ }^{60}$ The goal of antitrust squares with the biblical values of both equity and efficiency.

In his Godkin lecture, Arther Okun claimed: "We can't have our cake of market efficiency and share it equally." ${ }^{61}$ The conventional wisdom is that there is a trade-off between the pursuit of efficiency and the pursuit of income equality. ${ }^{62}$ True, the operating assumption of most economic analyses is to hold the distribution of income constant (or assume it as given) and, from that, to analyze efficiency problems. But no one seriously entertains the notion that some distributions of income, because of their structure of incentives and rewards, will not yield a larger basket of output than others.

In light of this trade-off, it is notable that antitrust enforcement generally serves to help those at the low end of the income distribution range without decreasing economic efficiency. Antitrust achieves this double benefit when it promotes efficiency in resource allocation by preventing the cartelization or monopolization of markets patronized by low-income consumers. The economic logic is straightforward: Prices will be made lower in a competitive market so that for any given income, a larger basket of goods and services can be purchased. Antitrust policy, therefore, need not concern itself with increasing the purchasing power of the poor because it does this when it thwarts cartels and monopolies in its pursuit of economic efficiency.

57 This section draws upon Kenneth Elzinga, "Goals of Antitrust: Other than Competition and Efficiency, What Else Counts?,” University of Pennsylvania Law Review, vol. 125, no. 6 (1977), Pp. 1191-1213.

${ }^{8}$ Psalm 99:4; Proverbs 1:3.

59 Luke 6:20.

60 Proverbs 31:27; Psalm 90:12; Proverbs 21:5; Psalm 39:4-5.

61 Arthur Okun, Equality and Efficiency, the Big Tradeoff (Washington, DC: The Brookings Institution, 1975)

62 C. Brehm and T. Saving, "The Demand for General Assistance Payments," American Economic Review, vol. 54, no. 1 (1964), pp. 1002-1018. 
Antitrust actions may not always improve both income distribution and efficiency. For example, the breakup of a cartel of artist-merchants who handcraft porcelain will be efficient but will bestow its distributional benefits only upon the economically privileged who shop in this market, thus arguably increasing inequality. But such situations are not the norm - in most circumstances antitrust gives the efficiency-equality trade-off the characteristic of having one's cake and eating it too. While a direct assault on inequality through income redistribution might lead to a reduction in efficiency, a direct assault on inefficiency through antitrust will not necessarily result in any reduction in equality.

In sum, the pursuit of efficiency goals through antitrust enforcement is consistent with the objective of equitable distribution of income. ${ }^{63}$ This is not to say that antitrust policy alone is a sufficient redistributive tool. Most analyses of the poverty problem in the United States attach only minimal importance to inadequate antitrust enforcement as a causative agent. The problem of poverty is attributed more often to the low level of education and job skills of the poor, insufficient aggregate demand, the distorted incentives of current welfare policies, drug addiction and alcoholism, racial discrimination, and a cognitive bias in favor of short-term over long-term satisfaction. ${ }^{64}$ Thus, the pursuit of egalitarian income distribution through antitrust enforcement is likely to have limited results. ${ }^{65}$ Nonetheless, the congenial quality about antitrust is that the equity objectives that bear on its enforcement do not seriously conflict, and at times even harmonize, with the pursuit of economic efficiency.

63 Private recovery of treble damages, 15 U.S.C. 15 (1970), also has an apparent connection with this equity goal of antitrust. Not only is it supposed to promote equity by compensating the injured from the fruits of an antitrust violation, but it also reduces income inequality if we make the assumption that those who commit violations generally have higher incomes than those they injure.

64 See Robert J. Lampman, “Approaches to the Reduction of Poverty," American Economic Review, vol. 55, no. 1 (1965), pp. 521, 524-525. See generally Edward Banfield, The Unheavenly City (Boston, MA: Little Brown and Co., 1970).

65 In fact, antitrust pursuit of equity goals is foreclosed in some areas. For example, those "restraints of trade" effected by labor unions and minimum wage laws directly contribute to income maldistribution, but, with only a few exceptions, antitrust is unable to strike at labor market restraints. In Apex Hosiery Co. v. Leader, 310 U.S. 469 (1940), the Sherman Act was held not to apply to "restraints on the sale of the employee's services to the employer." Ibid., 503. See also United States v. Hutcheson, 312 U.S. 219 (1941). The broad union exemption under Apex Hosiery was narrowed in Connell Constr. Co., Inc. v. Plumbers \& Steamfitters 100, 421 U.S. 616 (1975). Antitrust also has made important inroads on restraints upon competition by professional associations. For example, Goldfarb v. Virginia State Bar, 421 U.S. 773 (1975). 


\subsubsection{The Morality of Competition}

Antitrust policy is predicated on the assumption that business firms will create public benefits when they compete hard against one another by improving products and offering lower prices, or what Scherer and Ross describe as "conscious[ly] striving against other business firms for patronage ... for potentially incompatible positions." ${ }^{" 66}$ Christian thinkers continue to debate competition as a matter of Christian ethics and morality. ${ }^{67}$ One can debate, for example, how Jesus' admonition to turn the other cheek $^{68}$ and Paul's admonition to train ourselves like competitive athletes and run the competitive race before $\mathrm{us}^{69}$ inform Christian ethics in the marketplace.

There are several ways to reconcile these ostensible (and, we believe, only ostensible) conflicts in Scripture. Competition as an industrial value need not imply a society organized on selfish and ruthless disregard of others, or what C. S. Lewis gives as the state of hell: "A state in which everyone is perpetually concerned about his own dignity and advancement ... where everyone lives the deadly serious passions of envy, self-importance, and resentment." ${ }^{\circ}$ To the contrary, competition can be salutary for society and for the individual competitor.

First, antitrust policy is focused on a systemic rather than personal level, and as such, it is designed to advance social welfare. On average, what producers lose through competition is more than made up for by consumers' gains. ${ }^{71}$ Thus, an antitrust policy mandating competition rather than cooperation is not designed to enrich some at the expense of others, but rather to confer public benefits. The public benefits of market interactions may be seen as the sum of the mutual benefits gained by individuals in Smith's "obvious and simple system of natural liberty." Bruni and Sugden (2013) argue that mutual benefit is not only a fortunate by-product of the pursuit of self-interest, but actually the telos of the market: that buyers and sellers in a competitive

66 F. M. Scherer and David Ross, Industrial Market Structure and Economic Performance (Dallas, TX: Houghton Mifflin, 1990).

${ }^{67}$ Clive Breed has assembled recent literature in "Jesus and Competition," Faith \& Economics, vol. 45, no. 1 (Spring 2005), pp. 41-57.

68 Matthew 5:39.

69 Hebrews 12:1-2; I Corinthians 9:27.

70 C. S. Lewis, The Screwtape Letters (London: Geoffrey Bles, 1942), p. vii.

${ }^{71}$ Robert Bork, The Antitrust Paradox (New York: Basic Books, 1978), p. 110. 
marketplace actually intend for mutually beneficial transactions. ${ }^{72}$ Thus, in preserving competition among producers, antitrust enables the marketplace to flourish in the mutually beneficial manner that an economy of central planning or rent-seeking does not produce. As Paul Rubin has argued, market competition is a form of unplanned cooperation to secure systemic economic benefits. $^{73}$

Even at a personal level, competition within ethical and legal boundaries can be considered salutary for all involved. Shane Clifton argues from the Pentecostal tradition that "[c]ompetition is not a way for the powerful to crush the powerless, but for each person to reach their potential." 74 In the same way that an athlete running her hardest may hope to spur on her rivals to better performances, the Christian in business who competes hard for business need not wish her rival to perish, but may indeed hope that her competition spurs other firms to improvement. As Judge Learned Hand recognized in the Alcoa case, "Many people believe that possession of unchallenged economic power deadens initiative, discourages thrift and depresses energy; that immunity from competition is a narcotic, and rivalry is a stimulant, to industrial progress; that the spur of constant stress is necessary to counteract an inevitable disposition to let well enough alone." ${ }^{\prime 5}$

Finally, although antitrust law requires competition, it also establishes limits on competition (i.e., prohibiting predatory or anticompetitive tactics), as do separate strands of law, particularly contracts, torts, intellectual property, and the law of unfair competition. Thus, the competition that antitrust law mandates is not cutthroat or unlimited, but bounded by legal principles grounded in ethics and morality.

\subsubsection{Innovation}

Among contemporary economists, there is widespread agreement that market systems promote innovation. There is considerably less agreement on whether antitrust enforcement promotes for innovation, or whether it instead gets in

${ }^{72}$ Luigino Bruni and Robert Sugden, "Reclaiming Virtue Ethics for Economics," Journal of Economic Perspectives, vol. 27, no. 4 (2013), pp. 141-164.

73 Paul H. Rubin, "Emporiophobia (Fear of Markets): Cooperation or Competition?," Southern Economic Journal, vol. 80, no. 4 (2013), pp. 875-889.

74 Shane Clifton, "Pentecostal Approaches to Economics," in The Oxford Handbook of Christianity and Economics, ed. Rachel M. McCleary (Oxford: Oxford University Press, 2014), p. 275 .

75 United States v. Aluminum Co. of America, 148 F.2d 416 (1945). 
the way. This debate is often styled as the Schumpeter-Arrow divide, following the work of the Austrian economist Joseph Schumpeter and the American Nobel Laureate Kenneth Arrow, ${ }^{76}$ and has taken a prominent place in recent antitrust enforcement actions in high-tech industries, such as those concerning Microsoft, Google, and Intel. We do not propose to resolve the Schumpeter-Arrow divide here but rather offer more general comments on the value of economic innovation from a biblical perspective.

As mentioned earlier, faulty narratives often have portrayed Christianity as historically antagonistic to innovation. But both Christian theology as well as Church history are positively disposed to innovation. ${ }^{77} \mathrm{~A}$ thorough historical analysis demonstrates the connection between Christian movements and innovation. Rodney Stark has argued that Christianity, by focusing on theological abstraction and rationality and recognizing property rights, became a catalyst for technological and scientific innovation throughout Western Europe.$^{78}$ Joel Mokyr has disputed what he views as Stark's "argument based on some inherent superiority of Western or Christian culture" in advancing innovation, but does credit the Puritan embrace of science as a driving force behind the British Industrial Revolution. ${ }^{79}$

In the antitrust pursuit to "depart from laissez faire in the ultimate interests of laissez faire," ${ }^{80}$ the antitrust institution seeks to promote competitive processes that enable and incentivize innovation. This goal of promoting industrial innovation and progress finds ample support within a long-standing Christian tradition. Although Christian theology has relatively little to offer informing precisely how antitrust should spur innovation - whether by intervening aggressively to correct market failures or staying its hand out of solicitude for experimentation and robust competition - the Christian tradition strongly supports innovation as a goal.

${ }^{6}$ Herbert Hovenkamp, "Competition and Innovation," in The Making of Competition Policy: Legal and Economic Sources, eds. Daniel Crane and Herbert Hovenkamp (Oxford: Oxford University Press, 2013).

77 Anne Bradley catalogues the relationship between Christianity and Innovation in her article "Innovation, Change, and Economic Growth: A Christian Economist's Perspective," Institute for Faith, Work and Economics, March 11, 2013, https://tifwe.org/innovation-change-economicgrowth-a-christian-economists-perspective/. She writes that the Bible documents and upholds innovation in the forms of Construction (Genesis 6:14; 1 Kings 5-6), Metallurgy (Proverbs 25:4; Zechariah 13:9; Isaiah 48:10), Clothing (Genesis 37), and Shipping (James 3:4; John 21:11).

$7^{8}$ Stark, The Victory of Reason.

79 Joel Mokyr, A Culture of Growth: The Origins of the Modern Economy (Princeton, NJ: Princeton University Press, 2017), pp. 229, 314.

$8 \circ$ Joel B. Dirlam and Alfred E. Kahn, Fair Competition (Ithaca, NY: Cornell University Press, 1954), p. 17. 


\subsection{APPLICATION TO SELECTED DOMAINS OF ANTITRUST LAW}

\subsubsection{The Bible and Cartels ${ }^{81}$}

The quotation from Adam Smith that most antitrust lawyers know (particularly members of the plaintiffs' bar) is: "People of the same trade seldom meet together, even for merriment and diversion, but the conversation ends in a conspiracy against the public, or in some contrivance to raise prices." 82 Because price-fixing and other forms of cartel conduct occupy center stage in US antitrust enforcement, if there is any connection between the Christian faith and antitrust, it should show up here. And it does.

Suppose that a group of firms becomes weary of competing against each other so they divide up the market geographically, each firm agreeing not to poach on customers outside its designated territory. Or a group of sellers become unhappy with prevailing prices so they agree to a floor price below which sales will not be made. Or consider a market where prices are determined by competitive bidding, but sellers meet in advance in order to rig bid prices. Economists recognize each of these collective strategies as a variation of cartel behavior. Antitrust lawyers recognize each as being illegal per se under federal antitrust laws. The Bible, in turn, recognizes such concerted conduct as immoral.

The ninth commandment prohibits bearing false witness. ${ }^{83}$ This amounts to a condemnation of the deceptive nature of cartels as a matter of Christian morality. When a company holds itself out to its customers as an independent center of initiative in the marketplace, yet buyers are uninformed that the market has been parceled out, or that a floor price has been set, or that the bidding is phony, the firms in the cartel have borne false witness. Indeed, many cartel agreements involve the submission of bogus bids or other forms of dissimulation to prevent buyers from detecting the fact that quoted prices have been fabricated through collusion. Antitrust laws that deter cartels deter the bearing of false witness.

The ninth commandment, in its brevity, makes no distinction between white lies and major falsehoods. In like fashion, Section One of the Sherman Act draws no distinction as to whether the cartel raises prices and restricts

${ }^{81}$ This section draws upon Kenneth G. Elzinga, "Controversy: Are Antitrust Laws Immoral?

A Response to Jeffrey Tucker," Journal of Markets and Morality, vol. 1, no. 1 (1998), pp. 83-89.

82 Adam Smith, An Inquiry into Nature and Causes of the Wealth of Nations, ed. Edwin Cannan (Indianapolis, IN: Library of Economics and Liberty, 1904), p. 137.

83 Deuteronomy 5:20. 
output by large amounts or small. Participants in a cartel bear false witness whether the cartel is weak or strong.

Any decision by prospective members to form a cartel involves the calculation of prospective costs and benefits. Absent antitrust deterrence, the major economic hindrances to cartelization would be the free rider problem, cheating by members of the cartel, and fending off prospective new entrants. Absent antitrust deterrence against cartels, one of the major moral deterrences to cartelization would be any unwillingness on the part of sellers to portray themselves as independent economic agents - when they are not. Ceteris paribus, economics teaches that without antitrust deterrence, there will be more cartels. Antitrust is a concession to the inability of the ninth commandment to thwart cartels fully.

When the Justice Department announces a criminal enforcement action against companies or individuals involved in cartel agreements, it often issues a press release equating the price-fixing agreement to a form of theft from consumers. While we have no quarrel with that characterization, we would suggest that the Christian tradition emphasizes an additional evil of the cartel agreement - its inability to operate without a high degree of dishonesty and deception. ${ }^{84}$

\subsubsection{The Bible and Mergers}

If cartels are the meat and potatoes of antitrust enforcement, mergers and acquisitions are the soup and salad courses. Does the Christian faith offer a perspective on anticompetitive mergers and acquisitions as it does cartel conduct? Indirectly, yes.

A merger to monopoly may restrict output and raise prices (just as a cartel will do). Whether one considers these effects immoral depends upon whether one considers sellers extracting wealth from consumers by output restriction rather than by superior skill, foresight, and industry - to be immoral.

The Scriptures are favorably disposed to the pursuit of profits when it entails good stewardship over society's scarce resources, honesty in one's dealings, and honoring God by giving Him the first fruits of the return. ${ }^{85}$ Economic theory teaches that monopolistic output restriction is inefficient. Inefficiency

${ }^{84}$ Jonathan Crowe and Barbara Jedlickova describe the wrongness of cartels as pertaining to both the negative economic consequences of cartels to the competitive marketplace as well as the immorality of deception, which reflects the analysis in our chapter of cartels violating both economic and moral rules. Jonathan Crowe and Barbara Jedlickova, "What's Wrong with Cartels," Federal Law Review, vol. 44 (2016), pp. 401-418.

85 Proverbs 3:9-10. 
in a world of scarcity may itself be immoral from the standpoint of the biblical principle of stewardship. ${ }^{86}$

A business community that outwardly prides itself on the virtues of free enterprise, but engages in extensive horizontal integration that eliminates competing sources of supply, can hardly expect to persuade customers of the merits or the morality of free enterprise. For consumers, free enterprise connotes not only freedom of contract between buyers and sellers but also the freedom for buyers to shop among alternative sources of supply. At the taproot, that is what the antimerger law seeks to accomplish.

In a fallen world, many questions are hard to answer. Even antitrust experts often disagree on the merits of a particular merger. In the case of horizontal mergers, the combining firms may secure market power that will harm consumers or exploit economic efficiencies that will benefit consumers. The market may discipline a combination of business firms that, hindsight reveals, made no economic sense. It is sometimes tricky to sort mergers into competitive and anticompetitive categories. Should we, for that reason, give all corporate marriages a pass so long as all the firms come to the altar willingly? It is an act of faith (in markets, not the Scriptures) to believe we can dispose of antitrust in the merger arena just because antitrust authorities may sometimes stop benign or efficient mergers or neglect to unravel anticompetitive mergers.

\subsubsection{The Bible and Economic Dominance}

The third major heading of contemporary antitrust law is monopolization, or what the Europeans call "abuse of dominance." Monopolization remains a poorly defined antitrust offense, with significant ongoing policy contestation around such questions as whether dominant firms should be subject to special obligations to avoid perpetuating their dominance and where the line should be drawn between aggressive but permissible competitive behavior and unlawfully predatory behavior. Antitrust practitioners agree that the proverbial act of blowing up the competitor's factory should be considered monopolization, but consensus beyond that is scarce.

The Scriptures contain no secret code on how to write contemporary monopolization law, but they do provide ethical principles regarding the accumulation of earthly riches. On the one hand, the Scriptures are replete with warnings to the wealthy and powerful. For example, I Timothy 6:9-10 warns that the love of money is the root of all sorts of evil. And, in Luke 6:24, 
Jesus pronounces a woe to the rich, who have already received their consolation. But Jesus' parables also underscore the virtue of prudent investment, including reaping just rewards for risk-taking. In the Parable of the Bags of Gold, ${ }^{87}$ Jesus hypothesizes an employer who entrusts bags of gold - five, two, or one - to three servants while he's away on a journey. Upon his return, he learns that the servants with five or two bags made prudent investments during his absence, each doubling the master's principal, but that the third servant, entrusted with a single gold bag, hid it in the ground and therefore earned no return on investment. This servant attempts to justify himself on the basis that, knowing his master was a hard man, he ensured the safety of the money entrusted. His master rebuffs this excuse, pointing out that even a very safe investment with bankers would have garnered some interest, and has the "wicked and lazy" servant punished.

Although Jesus meant this parable to have a primarily spiritual connotation regarding the Kingdom of God, its economic moral buttresses a strand of monopolization jurisprudence holding that firms should not be penalized for reaping the benefits of their risky investments and that less efficient firms should not have standing to complain when their more efficient rivals grow market share: "For whoever has will be given more, and they will have an abundance. Whoever does not have, even what they have will be taken from them." 88

\subsection{CONCLUSION}

Geoffrey Brennan and Anthony Waterman make this statement about economics:

Economists have long paid lip service to the idea of economics as a pure science that cannot authorize them to offer "a single syllable of advice." [quoting Nassau Senior] But in practice, they have rarely been able to resist making policy recommendations of all sorts - recommendations that necessarily commit them to underlying normative foundations. As one influential moral philosopher has put it, thinking of economics as it is actually practiced, "economics is a branch of ethics ... (quoting Broome)." 89

Our analysis of the intersection of antitrust and Christianity runs parallel to that of Brennan and Waterman. While antitrust is about law and economics, antitrust is also about ethics. And the ethics of antitrust can be viewed

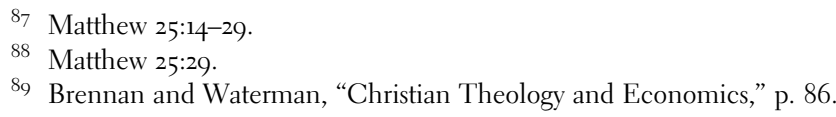


profitably (no pun intended) through the lens of the Christian faith. Indeed, the institution of antitrust connects with the Christian faith in several ways. The historical foundation of antitrust finds its roots in the Christian thinkers of the Scholastic tradition, the Reformation movement, and the Scottish Enlightenment. Adam Smith, the patron saint of economics, was himself influenced by the Presbyterian clergymen of the Scottish Enlightenment. Smith's "simple and obvious system of natural liberty" has been codified with the most famous metaphor in all of the social sciences: the invisible hand. It is this "simple and obvious system of natural liberty" - Smith's invisible hand which modern antitrust endeavors to protect and promote..$^{90}$

The themes of antitrust, such as rationality, equity, efficiency, competition, and innovation, are all congruent with biblical foundations and Christian principles. This chapter also explores a triad of contemporary applications of Christian thinking and antitrust litigation: cartelization, mergers, and economic dominance. Overall, we illustrate the deep interconnectedness - historically, thematically, and contemporarily - of the Christian faith with antitrust as a discipline.

90 Adam Smith's less well-known The Theory of Moral Sentiments can be read as a bridge between the Christian ethics of Hutcheson and the secular ethics of Hume. The many attempts to exegete what the discipline of economics means by the pursuit of self-interest is derivative of Smith's endeavor to mediate between Hume's dismissal of a supernaturally grounded basis for ethics and Hutcheson's insistence on a revelation revealed basis for morality. 